\title{
Ocean-Climate Interaction of South Eastern Indian Oceanfor Tuna Fisheries \& Its Socio-Economy Impacts
}

\author{
Widodo S. Pranowo ${ }^{1,2}$, Anastasia R.T.D. Kuswardani ${ }^{1,2}$, Budi Nugraha ${ }^{1}$, Dian Novianto ${ }^{1}$, \\ Umi Muawanah ${ }^{1}$, Hari Prihatno ${ }^{1}$, Weidong $\mathrm{Yu}^{3}$ \\ ${ }^{1}$ Agency for Marine \& Fisheries Research \& Development, Ministry of Marine Affairs \& Fisheries, Republic of Indonesia. \\ ${ }^{2}$ Department of Tech. Hydrography, Indonesian Naval Postgraduate School (STTAL) \\ ${ }^{3}$ Center for Ocean \& Climate Research, First Institute of Oceanography, State Oceanic Administration, P.R. China. \\ *Presented at the 16th IOTC Working party on Tropical Tuna, November 2014
}

\begin{abstract}
The complexity of the climate - ocean interactions in Indonesia is caused by the Indonesia's geographical position at the crossroads of the Indian and the Pacific Ocean. A periodic ENSO and non-periodic IOD affects Indonesian Monsoon system. A large volume of water masses from the Pacific Ocean that flows into the Indian Ocean passing through the territorial sea of Indonesia (Indonesian Through- flow) helps to provide a balance to the ocean climate in Indonesia as part their migration areas. For Tuna fisheries in Indonesia, Indian Ocean plays an important role for tuna's habitat. This article describes the physical condition of the South Eastern Indian Ocean based on archive data of the climate - sea survey, and also describes sustainable tuna habitat based on tuna catches surveys data. The southern part of Indian Ocean is a high primary productivity area for tuna because there is a periodic Java upwelling system occurred between June and October annually, and the eddy current system encourages nutrients and chlorophyll from the coast towards the open sea. This is an excellent ocean dynamics for the sustainable tuna fisheries.
\end{abstract}

Keywords: Ocean-climateinteraction, South Eastern Indian Ocean, tuna fisheries, socio-economic.

\section{Introduction}

Exploration to assess characteristic of the Eastern Indian Ocean has a history of its own, which has been done about 50 years ago. But It linkages with fisheries are rare as done in the Pacific Ocean and the Atlantic Ocean.

The Eastern Indian Ocean, especially in the west off Sumatra and south off Java has a quite complex sea-airinteraction, which was allegedly very closely related to the sustainability of fisheries. Particularly in the south of Java, there is a "semipeRmanentjAvacoasTal Upwelling" (RATU), that goes around of July until October in every year, that causes the high productivity in its region [1]. An existing of Eddies current is then pulling out primary productivity from coastal zone to the open seas, where tuna habitats exist there [2], [3].

This article describes the physical (i.e. Mixed Layer Depth) condition of the ecosystem in the East Indian Ocean based on archive data of the climate - sea survey (WOA 2009), and also describes sustainable tuna habitat survey data based on tuna catches data. Some literatures are used also for discussion and reviews particularly for its social and ecosystem impacts.

\section{Methodology}

We used three types of data. We used Mixed Layer Depth (MLD) data $\left(\Delta \mathrm{T}=0.5^{\circ} \mathrm{C}\right)$ and temperature data derived from WOA 2009 [4], [5] to describe normal conditions of the physical characteristic. For fisheries dataset we used the Tuna dataset collection which is provided by the Research
Institute for Tuna Fisheries (LPPT) Agency for Marine and Fisheries Research and Development Republic of Indonesia. An ocean current prediction dataset from HYCOM data archieve [6] is also used to investigate the tuna catchment area and its relation to eddy current.

\section{Results and Discussion}

\subsection{Relation between Mixed Layer Depth and Tuna Catch}

We tested the relationship between MLD and Tuna catches and between temperature and Tuna catches. The results can be seen in Figure 1 and Figure 2. Using a Pearson test, MLD and Tuna catch has a high positive relationship (corr. +0.891 ). This shows that the depth of the MLD and the catch of tuna have a strong positive linear correlation. This shows that the deeper the MLD, the more the tuna catch, particularly for big eye tuna. For TransitionalSeason 1 (March-May), it has the highest temperature at about $28.47^{\circ} \mathrm{C}$ but produces the lowest catch of 12,973 fishes. This is presumably due to the dissolved oxygen content in Transitional Season 1 in the distribution of tuna has a sufficiently low value, thus resulting in reduced number Tuna. 


\section{International Journal of Science and Research (IJSR) \\ ISSN (Online): 2319-7064}

Index Copernicus Value (2013): 6.14 | Impact Factor (2014): 5.611

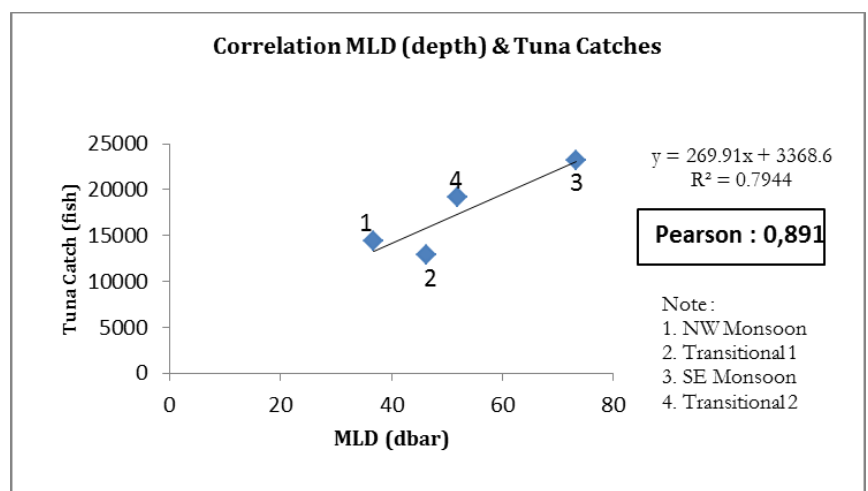

Figure 1: Corellation between Mixed Layer Depth [dbar] and Tuna Catchment [fish unit]

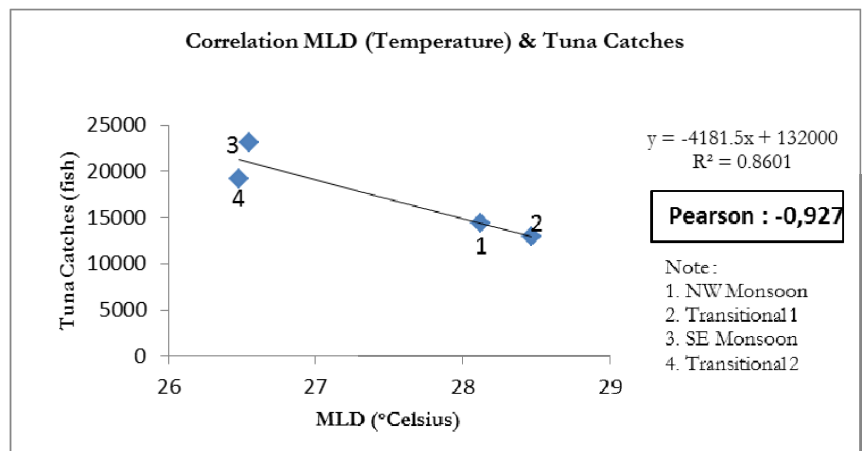

Figure 2: Corellation between Mixed Layer Depth $\left[{ }^{\circ} \mathrm{C}\right]$ and Tuna Catchment [fish unit]

For each season, we overlaid the MLD with tuna catch distribution. Catch distribution data is gathered bytuna observer of LPPT. Red line denoted the regional Fisheries Management Area (FMA) boundary. South Java Seain the South Eastern Indian Ocean belongs to the FMA 573.During North WestSeason (December-February), the tuna catch distribution is mostly at the MLD of 40 dbar or 40.79 meter with an average temperature around $29^{\circ} \mathrm{C}$ (see Figure 3 and Figure 4). The map shows that there are more tuna catch is outside the RFM (open seas). During the Transitional Season, tuna are distributed at the MLD of 50-60 dbar or 5161 meters with average temperatures ranging from 28.5 $29^{\circ} \mathrm{C}$ (see Figure 3 and Figure 4).

During South East Season (June-August), tuna are found more in the MLD of 70-90 dbar or 71,39 - 91,79 meters. In this season, the catch distribution is larger than those of the two previous seasons. This shows that the deeper the MLD, the larger the catch distribution. In addition, the temperature range in this season is relatively cooler at about $26.5-27^{\circ} \mathrm{C}$ (see Figure 3 and Figure 4). This low MLD temperature could be due to upwelling, the cold seawaterfrom deep carried to shallowerlayer. This upwelling is also accompanied by nutrient flow to the MLD layer. This makes the MLD layer becomes more high productivity. This explains why the high tuna catch distribution at MLD layer is happened duringSouth East Season than any other seasons.

DuringTransitional Season 2 (September-November), tuna is found more distributed at MLD of $50-60 \mathrm{dbar}(\sim 51-61 \mathrm{~m})$, having temperatures ranging from 26 to $27^{\circ} \mathrm{C}$ (see Figure 3 and Figure 4). The MLD of this season is shallower than during South East Season. This is in accordance with smaller tuna catch distribution.

There are even more interesting evidence about the relationship between the physical aspects of the South of Java Sea as part of Eastern Indian Ocean, that based on tuna vessels (coordinates) during February - July 2013, generally shows the operation area of tuna catchment are fitted to eddies current location which is also in accordance with MLD area, see Figure 5.

\subsection{Upwelling Variations for Sustainable Fisheries}

Sumatra-Java-Timor upwelling area, as the target location of the near future of Eastern Indian Ocean Upwelling Research Initiative (EIOURI) project (2016-2019/2020), has a strong relation to the Fisheries Management Areas (FMA) 572 (Indian Ocean - west Sumatera) and 573 (South of Java East Nusa Tenggara), are two fisheries management area among eleven FMAs that located within the Indian Ocean Tuna Commission (IOTC) area of competence [7]. Long line contribute a bigger proportion (44\%) of tuna catch compare to other gears and the number of active long liners registered and operated on the two FMAs is grown up from 1118 vessels in 2011 become 1227 vessels in 2013 [7], [8].But this article is now only further discuss about FMA 573.

The Indonesian statistic catch of four main tuna species in 2009 is estimated 101.292 ton, and 2012 is estimated 168.626 ton; while the total catch for all species by all gears type tend to increase to just above $600,000 \mathrm{mt}$ in 2010 and 398,540 ton in 2012 [7], [8]. The understanding of the climate variability and its relation with biogeochemistry dynamic will be an important basis to enhance the regulation and policy for the fisheries management to minimizing an ilegal, unreported, and unregulated fishing. Furthermore, It will be minimizing the mean error catchment data linkage with the vessel monitoring system due to improve the fish stock assessment database.

There are 3 primary fishing ports/landing sites of South East Indian Ocean tuna for industrial (i.e. Nizam Zachman Fishing Port at Muara Baru, Jakarta; Cilacap Fishing Port, Central Java; and Benoa Fishing Port, Bali), which are impacted by the ocean-atmosphere interaction. Merely also at least 6artisanals (i.e. Pelabuhanratu\&Prigi at South Coast of Java; Kedonganan \&Jimbaran in Bali; Ende in Flores;and Kupang in Timor), as the potential growth area of generating small scale fishery, could be affected by intra-seasonal and interannual variability of South East Indian Ocean. In facts, July and October the fishing location are distributedat off of Cilacap Artisanal Fishing Port.The gillnet base isobserved during 2008-2010,its peak of production shows closely compared to April [9]. According to the upwelling index, July is the upwelling peak, and its follows by the peak of fish landed, in Cilacap,in October [10].

South Java Sea of Indonesian territory (FMA 573) which connected to South East Indian Ocean is a spawning area and a nursery ground of the Southern Bluefin Tuna (SBT).They have two spawning peaks, i.e. during October-November and January-February [11].According [11], juveniles migrate

\section{Volume 5 Issue 4, April 2016}




\section{International Journal of Science and Research (IJSR) \\ ISSN (Online): 2319-7064 \\ Index Copernicus Value (2013): 6.14 | Impact Factor (2014): 5.611}

seasonally southwards along the west coast of Australia and stay in the coastal waters of the South West, South, and South East of Australia; and also in the central part of Indian Ocean. Furthermore [11] said that, as the fish grow area, they extend their distribution to cover the circumpolar area throughout the Indian, Pacific and Atlantic Oceans. The spawning ground of Southern Bluefin Tuna is considered to
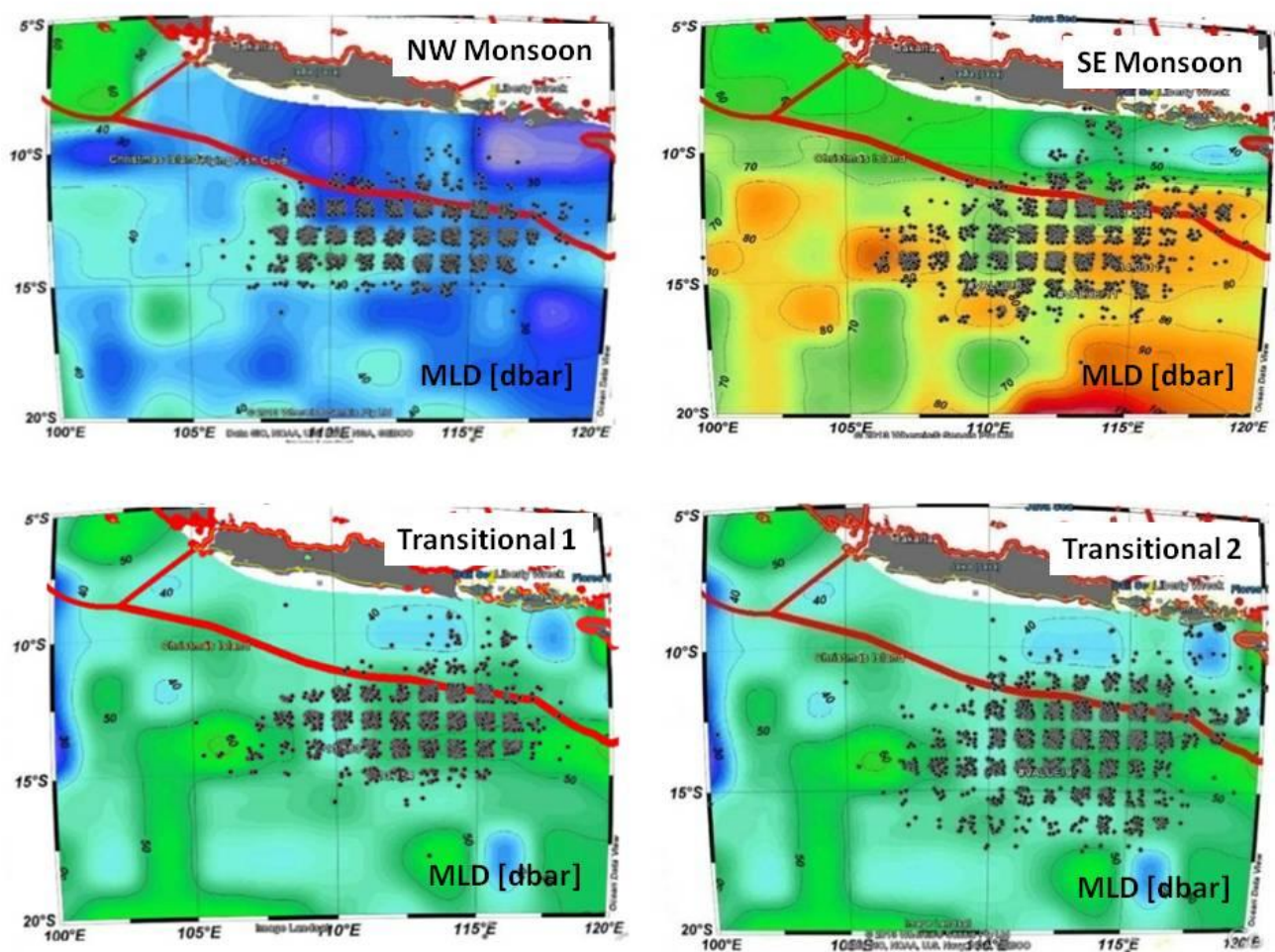

Figure 3: A seasonally climatological Mixed Layer Depth [dbar] (shows in shaded colors) in South Java of the Eastern Indian Ocean overlayed with Tuna vessels distributions. Red lines is An Indonesia Fisheries Management Area's boundaries (FMA573)
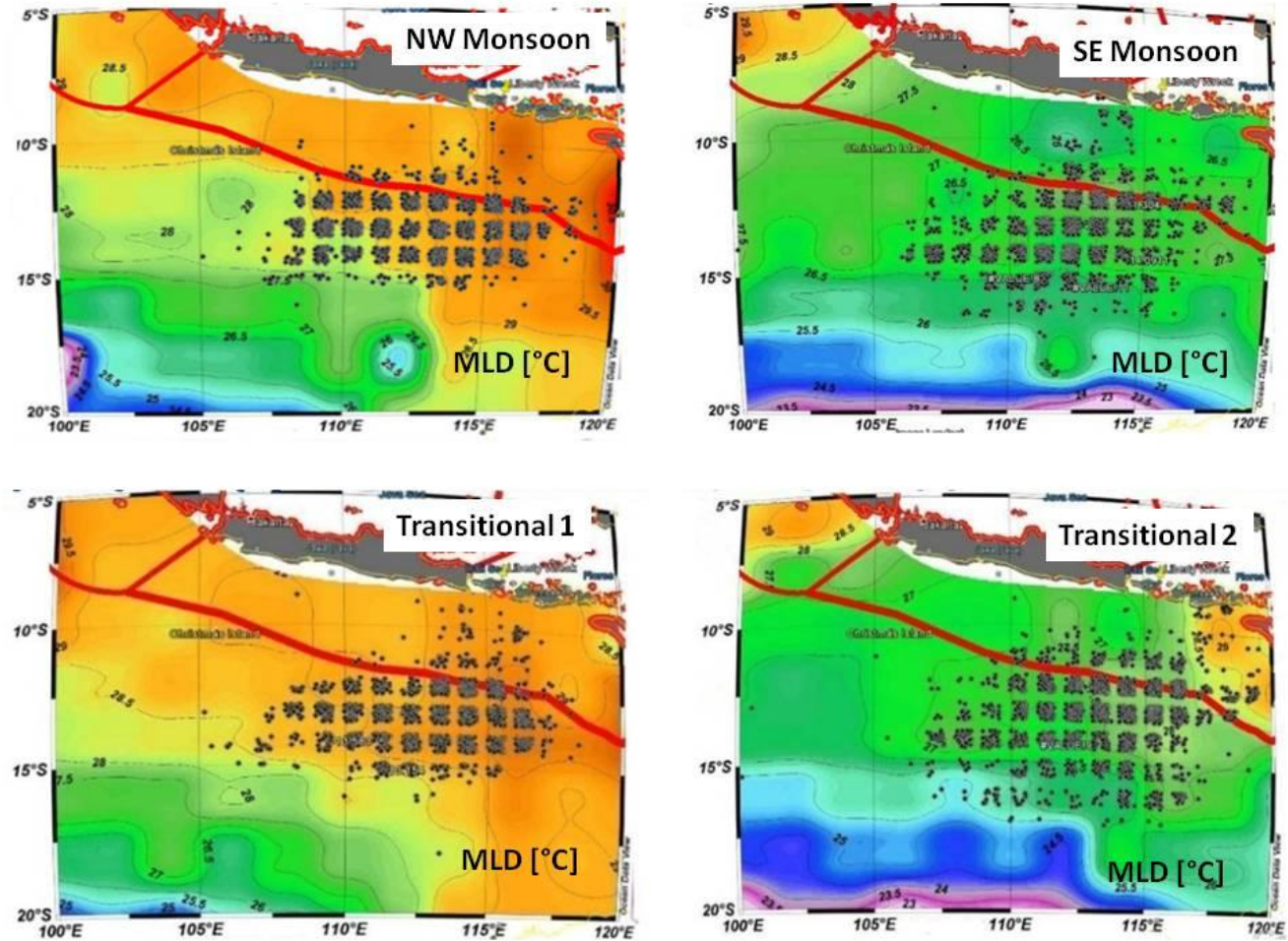

Figure 4: A seasonally climatological of Mixed Layer Depth $\left[{ }^{\circ} \mathrm{C}\right]$ (shows in shaded colors) in South Java of the Eastern Indian Ocean overlayed with Tuna vessels distributions. Red lines is An Indonesia Fisheries Management Area’s boundaries

(FMA-573)

\section{Volume 5 Issue 4, April 2016} www.ijsr.net 


\section{International Journal of Science and Research (IJSR)}

ISSN (Online): 2319-7064

Index Copernicus Value (2013): 6.14 | Impact Factor (2014): 5.611
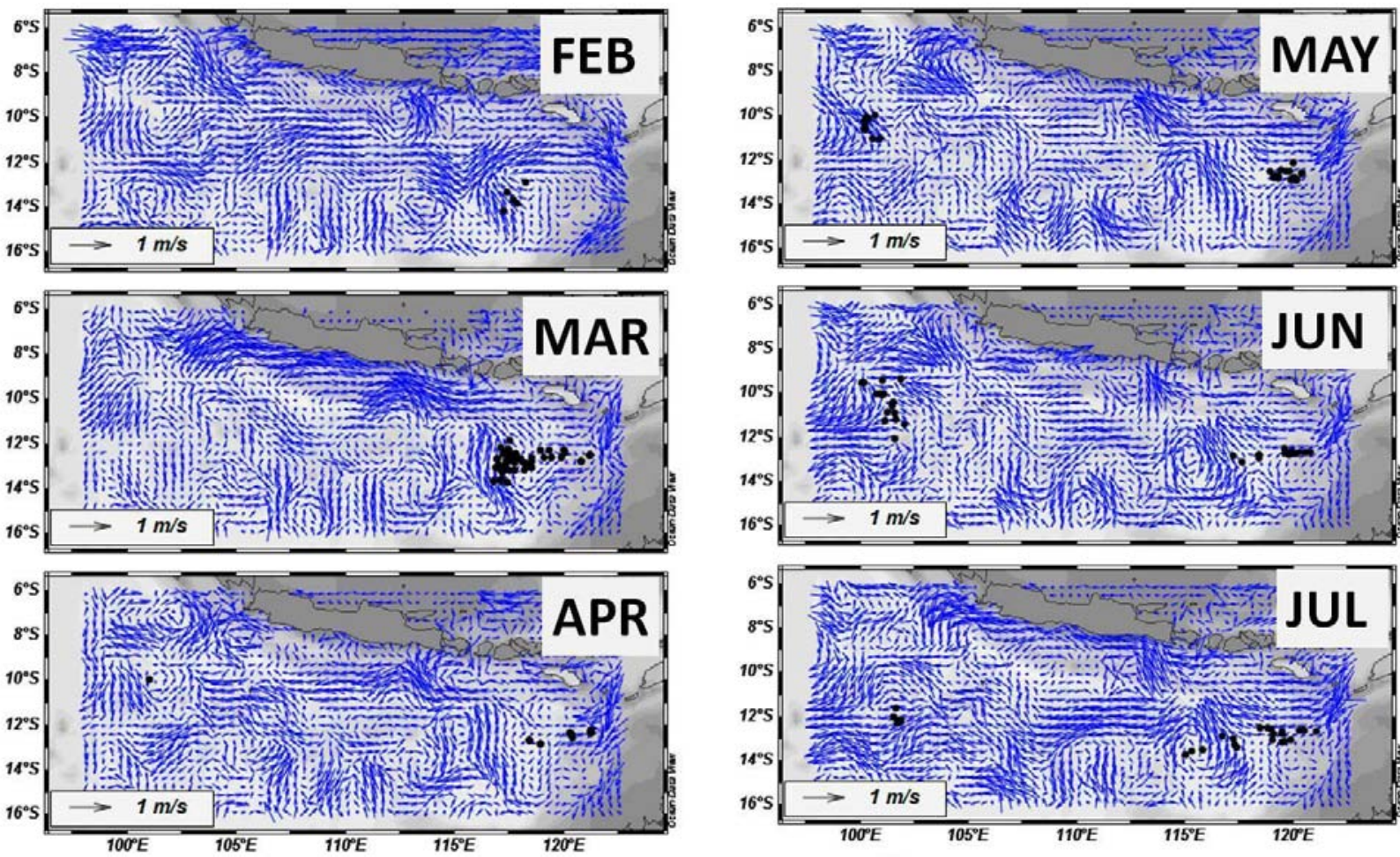

Figure 5: Tuna vessels (black dots) are mostly fishing in the eddies curents zone, during February - July 2013. Coordinate tuna vessels collected by LPPT, while ocean current is derived from HYCOM archieve dataset

[15] in his article, assume that is not only environmental factors influencing tuna catch season. Any fishing activity will potentially have ecosystem effects. By harvesting fish, humans assume the functional role of a top predator in the system. The magnitude of the ecosystem effects will be depending both on the functional role of the fish being harvested and the magnitude of the removals from the system. [15] is also emphasized, in the case of tuna fisheries and pelagic ecosystems, there is a lack of data and understanding of the effects on the functioning of the ecosystem as the result of changed abundances in the tuna component. However, the magnitude of the removals can provide some indications of when any potential effects, if they occurred, would most likely have manifested themselves.

The major significant impacts of tuna catches to ecosystem function would have been expected to have begun in the mid 1980s. The increasing of the total catch from tuna fisheries, in the Indian Ocean, will be a high linearly followed by decreasing the catch rate.Current total removals for the Indian Ocean are estimated more than 600,000 mt[15], [8]. A kind of research extension to enhance analysis on the Indian Ocean carrying capacity including its fisheries stock assessment is proposed for further development on catchment quota regulation [16].

\subsection{Physical-Biogeochemistry Dynamics and The Development on Marine Protected Management}

In order to complimentary to the Fisheries Management Area (RMA), Government of Indonesia published the Indonesia Marine Ecoregion (Ekoregion Laut or EL, in Bahasa) Map which purpose to be a reference for the development of the management long-term plan of marine protected area. The marine ecoregion map is mainly generated by the geographical condition, seawater properties characteristic, and the biodiversity/ecosystems [17]. There 18 marine ecoregion (EL) for Indonesian seas territory. The FMA 573 is correlated with EL-2 (South of Java) and EL-9 (South of Bali and Lesser Sunda Islands).

We have an experiences, that the data and information, which is resulted from the Indonesia-China research project on "Monsoon Onset Monitoring and Its Social and Ecosystem Impacts" (MOMSEI) during 2013South Java Upwelling cruises, used as one of the reference for the development of Indonesia Marine Ecoregion Map to support the national action plan for climate change adaptation [18].

Ecoregion map may also serve as a reference area for the further control and management plan offishing season. The South Java Sea is a nursery ground for southern bluefin tuna. However, the tuna migrates to Tasmania and Australia when they reach adulthood. Hence, its management lies both in Indonesia and Tasmania Seas. One possible multinational management for the southern bluefin tuna is agreement among these three countries to manage the fishery from the nursery until their adulthood. This can be done by benefit transfer from the country that harvest tuna to the country that keeps the nursing ground in healthy.

Sumatra-Java-Timor high biodiversity which influenced by a regional physical-biogeochemistry dynamics will be an important knowledge to enhance the second level of the Marine Ecoregion Map. In the near future second level of the map, the comprehensive vertical layering variability of marine characteristic aspects will help to define further 


\section{International Journal of Science and Research (IJSR) \\ ISSN (Online): 2319-7064 \\ Index Copernicus Value (2013): 6.14 | Impact Factor (2014): 5.611}

delineation of the sub marine ecoregion of South Java Sea(EL-2), and South of Bali - Lesser Sunda Islands (EL-9).

\section{Conclusion and Recommendation}

The Mixed Layer Depth (MLD) and the catch of tuna in the South Eastern Indian Ocean havea strong positive linear correlation. High tuna catch distribution at MLD layer is happening during Southeast Season than any other seasons.

In Northwest Season, the tuna catch distribution is mostly at the MLD of 40 dbar or 40.79 meters with an average temperature around $29^{\circ} \mathrm{C}$. During the Transitional Season, tuna are distributed at the MLD of 50-60 dbar( 51-61 meters) with average temperatures ranging from $28.5-29^{\circ} \mathrm{C}$. During South EastSeason, tuna are found more at the MLD of 70-90 dbar ( 71.39 - 91.79 meters). In this season, the catch distribution area is larger than those of the two previous seasons.

The South Eastern part of Indian Ocean is a high primary productivity area for tuna because there is a periodic Java upwelling system occurred between June and October annually, and the eddy current system encourages nutrients and chlorophyll from the coast towards the open sea. This is an excellent tuna habitat for the sustainable production of tuna fisheries.

\section{Acknowledgment}

Awards to give to students who joyfull working in Marine and Coastal Data Laboratory, Agency for Marine and Fisheries Research and Development: Restu Wardani (Univ. Diponogoro), Dessy Teliandi (Institut Teknologi Bandung), and Hilda Heryati (Univ. Padjadjaran), they are making beautiful plots. This work is funded by Indonesian National Development Budget (DIPA APBN) TA 2013/2014 for "Monsoon Onset Monitoring \& Its Social \& Ecosystem Impacts (MOMSEI)" project, while its publication and travel is funded by DIPA APBN TA 2015/2016 for same project. We gratefully thank to Prof. Dr. SomkiattKhokiattiwong (Pukhet Marine Biodiversity Center) who facilitate sharing idea and discussion during writing the EIOURI Eastern Indian Ocean Upwelling Research Initiative (EIOURI) Science Plan and Implementation Strategy (SPIS) Group Meeting 9-12 Apr. 2014, in the beautiful Phuket beach, Thailand. This article has been presented at the 16th Indian Ocean Tuna Commission (IOTC) Working Party on Tropical Tuna (WPTT) Conference November 2014, and some adjustment and editing was made recently in 2016.

\section{References}

[1] W.S. Pranowo, "Fenomena di Laut Selatan Jawa tersebut kami Beri Nama "RATU"," Indonesia Maritime Magazine (eds.) 44/IV, pp. 44-45, 2014.

[2] W.S. Pranowo, H. Philips, S. Wiffels, "Upwelling Event 2003 Along South Java Sea and Lesser Sunda Islands," Journal Segara I (2), pp. 63-67, 2005.

[3] A. Tussadiah, M.L. Syamsuddin, W.S. Pranowo, N.P. Purba, I. Riyantini, "Eddy vertical structure in Southern
Java Indian Ocean: identification using Automated Eddies Detection," International Journal of Science and Research V (3), pp. 967-971, 2016.

[4] G. Monterey, S. Levitus, "Seasonal Variability of Mixed Layer Depth for the World Ocean," NOAA Atlas NESDIS 14, 1997.

[5] R.A. Locarnini, A.V. Mishonov, J.I. Antonov, T.P. Boyer, H.E. Garcia, O.K Baranova, M. M. Zweng, D. R. Johnson, World Ocean Atlas 2009, Volume 1: Temperature. S. Levitus, Ed. NOAA Atlas NESDIS 68, U.S. Government Printing Office, Washington, D.C, 2010.

[6] J.A. Cummings, O.M. Smedstad, "Variational Data Assimilation for the Global Ocean," Data Assimilation for Atmospheric, Oceanic and Hydrologic Applications III (13), pp. 303-343, 2013.

[7] F. Satria, Mahiswara, A. Widodo, L. Sadiyah, S. Tampubolon, "INDONESIA National Report to the Scientific Committee of the Indian Ocean Tuna Commission, 2011," Report No.: IOTC-SC14-NR10, 2011.

[8] F. Satria, H.E. Irianto, B. Nugraha,L. Sadiyah, "INDONESIA National Report to the Scientific Committee of the Indian Ocean Tuna Commission, 2013,” Report No.: IOTC-SC16-NR10, 2013.

[9] A.A. Widodo, F. Satria, L. Sadyiah, J. Riyanto, "Neritic Tuna Species Caught Drifting Gillnet in Indian Ocean Base in Cilacap Indonesia," IOTC Report No. IOTC2011-WPNT01-21, 2011.

[10] R.T.D. Kuswardani, "Determination of Upwelling Index Based On Three Dimensional Numerical Modeling \& Its Relation With Fish Catch," In Proceedings of the Seminar Hasil Penelitian Terbaik, pp. 155-163, 2013.

[11] S. Tsuji, "Stock Status of Southern Bluefin Tuna," Proceed. 7th Expert Consult. On Indian Ocean Tunas, Victoria, Seychelles, pp. 219-226, 1998.

[12] C. Shinguu, "Ecology \&Stock of SouthernBluefinTuna," CSIRO Mar. Lab. Rep131, 1981.

[13] Y. Nishikawa, M. Honma, S. Ueyanagi, S. Kikawa, "Average Distributionof Larvae of OceanicSpecies of ScombridFishes 1965-1981," Far Seas Fish. Res. Lab S. Ser XII, 1985.

[14] H. Matsuura, T. Sugimoto, M. Nakai, S. Tsuji, "Oceanographic ConditionsNearThe Spawning Ground of Southern Bluefin Tuna; Northeastern Indian Ocean," Journal Oceanography LIII, pp. 421-433, 1997.

[15] T. Polacheck, "Tuna LonglineCatchRates in The Indian Ocean: Did IndustrialFishingResults in a $90 \%$ RapidDecline in The Abundance of LargePredatorySpecies," Journal Marine Policy XXX, pp. 470-482, 2006.

[16] OPRT, "World Major Tuna Longliners Suspend Fishing," The Org. Promot. Respon. Tuna Fish. Newslett. Intl. XX,pp.2-5, 2008.

[17] L. Rosalina,Hendaryanto, E.T. Kurniawaty, F. Mohammad, N.E. Putri, G.H. Pramono, D. Trie W.S., Y.H. Ramadhani, W. Pranowo, I.R. Suhelmi, D. Purbani, H.Y. Siry, Mahdan, O.N. Marwayana, Y. Darlan, Y. Permanawati, A. Sudaryanto, M. Hutomo, H.A. Susanto, E. Riani, M. Khazali, 


\section{International Journal of Science and Research (IJSR) \\ ISSN (Online): 2319-7064 \\ Index Copernicus Value (2013): 6.14 | Impact Factor (2014): 5.611}

"DeskripsiPetaEkoregionLaut Indonesia," KementerianLingkunganHidupRepublik Indonesia, pp. 228, 2013.

[18] W. S. Pranowo,T.R. Adi, A.R.T.D. Kuswardani, S.L. Sagala,B. Sulistiyo,"Research Activities on OceanClimate Variability Impact to Marine \& Fisheries Sector," in Proceedings United Nations/Indonesia International Conference on Integrated Space Technology Application to Climate Change, 2013.

\section{Author Profile}

Widodo S. Pranowo is now as Head of Marine and Coastal Data Laboratory, in Research \& Development Center for Marine \& Coastal Resources, Agency for Marine \& Fisheries Research \& Development, under the Ministry of Marine Affairs \& Fisheries, Republic of Indonesia. During 2013-2014, he was appointed to be Coordinator of Indonesian Research Scientists for Indonesia China Monsoon Onset Monitoring and Its Social and Ecosystem Impact (MOMSEI). Since 2016, he is a member of National Working Group on Climate Change Adaptation and Mitigation for Marine and Fisheries Activities. He is also active as reguler lecturer of adjustment computation, in Indonesian Naval Postgraduate School (STTAL).

Anastasia R.T.D. Kuswardaniholds a $\mathrm{PhD}$ in Physical Oceanography from China Ocean University, in 2012. Since 2014, she is appointed to be Head of Research Group on Climate Change Policy in the R \& D Center for Marine \& Coastal Resources, Agency for Marine \& Fisheries Research \& Development, Ministry of Marine Affairs \& Fisheries, Republic of Indonesia. During 20152016, She is appointed to be director for Indonesia China Center for Ocean Climate. Since 2016, he is a member of Expert Team for National Working Group on Climate Change Response for Marine and Fisheries Activities. She is also active as reguler lecturer of oceanographic modelling, in Indonesian Naval Postgraduate School (STTAL).

BudiNugrahaholds a M.Sc in Fisheries Capture Technology from Bogor Agriculture University (IPB), in 2009. Currently, He is the head of Research Institute for Tuna Fisheries (LPPT), Agency for Marine \& Fisheries Research \& Development, Ministry of Marine Affairs \& Fisheries, Republic of Indonesia. He is an active member of Working Party on Tropical Tuna, Indian Ocean Tuna Commission (IOTC) as a representative of Indonesian Government. He is an active member of Working Party on Tropical Tuna, Indian Ocean Tuna Commission (IOTC) as a representative of Indonesian Government.

Dian Noviantois now a Master Student in Environmental Science of Udayana University. Previously, he has Bachelor Degree, in 2000, in Marine Resources Management from Jakarta Fisheries University. Currently, he is research associate in the Research Institute for Tuna Fisheries (LPPT), Agency for Marine \& Fisheries Research \& Development, under Ministry of Marine Affairs \& Fisheries, Republic of Indonesia.He is also an active member of Working Party on Tropical Tuna, Indian Ocean Tuna Commission (IOTC) as a representative of Indonesian Government.

UmiMuawanahholds a $\mathrm{PhD}$ in Enviromental and Resources Economics from University of Connecticut, USA in 2013. Currently, she is a research associate in the Research \& Development Center for Socio-Economics of Marine \& Fisheries, Agency for Marine \& Fisheries Research \& Development, under Ministry of Marine Affairs \& Fisheries, Republic of Indonesia. She is also active member of Expert Team for Marine \& Fisheries Policy Corner.
Hari Prihatnoholds a M.Sc in Management Planning for Coastal \& Rivershed from University of Gadjah Mada in 2011. Currently, he is a research associate in the Research \& Development Center for Marine \& Coastal Resources, Agency for Marine \& Fisheries Research \& Development, under Ministry of Marine Affairs \& Fisheries, Republic of Indonesia. He has experience in many scientific expedition cruises in national and regional scope. One of them was the IOC/WESTPAC project "Responses of Marine Hazards to Climate Change in the Western Pacific" in the South China Sea, 2012.

WeidongYuis Director of Center for Ocean \& Climate Research, First Institute of Oceanography, State Oceanic Administration, P.R. China. He is the IOC/WESTPAC Regional Project Leader on Monsoon Onset Monitoring and Its Social and Ecosystem Impact (MOMSEI). He is also a Coordinator for Chinese research scientists for Indonesia - China Joint Collaboration on MOMSEI, since 2010. 